Prepared in cooperation with the Indiana Department of Transportation

\title{
Flood-Inundation Maps for the White River at Noblesville, Indiana
}

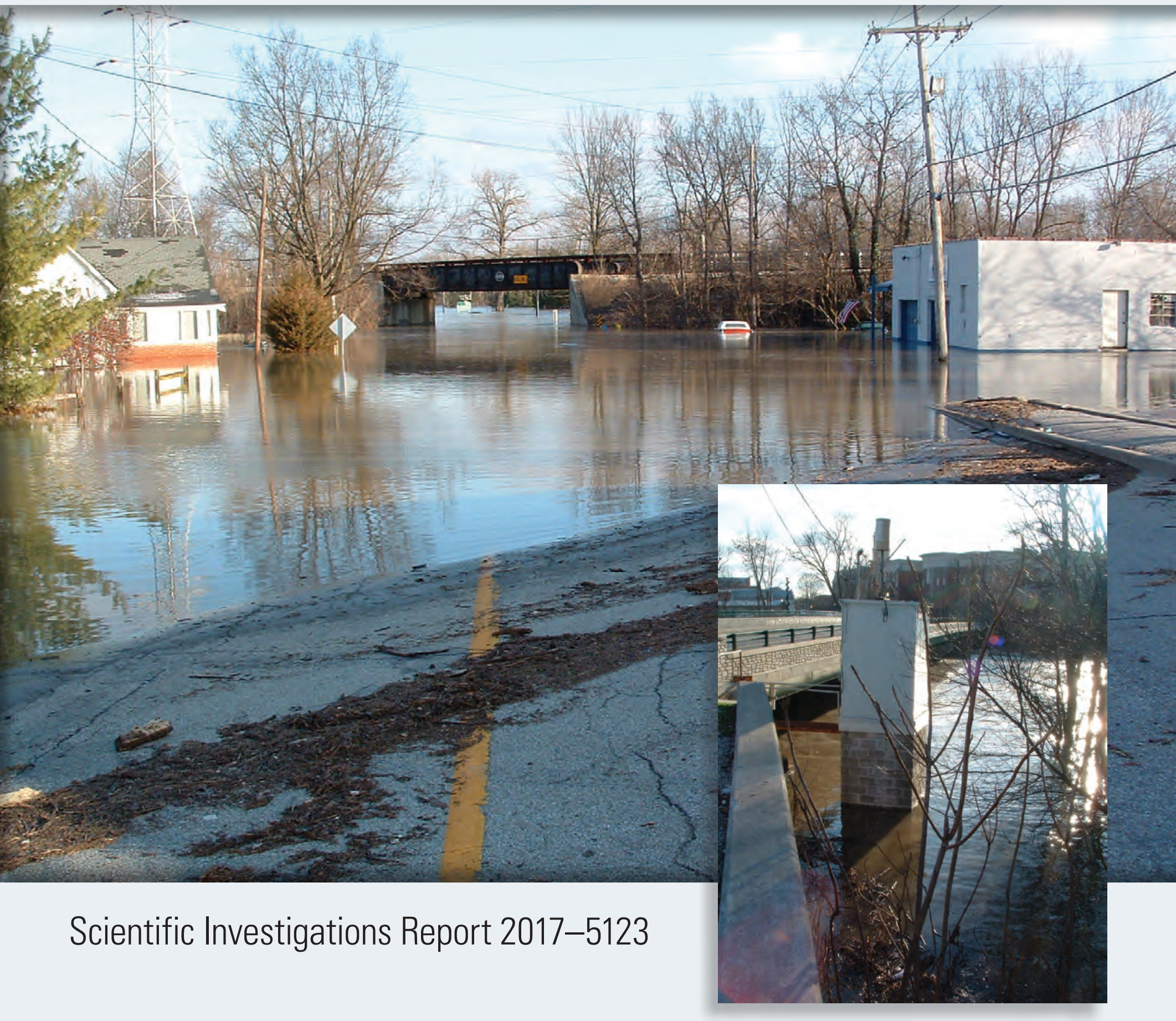

U.S. Department of the Interior

U.S. Geological Survey 
Cover. Photographs taken by U.S. Geological Survey hydrologic technician John Poehler during a field visit of the White River at Noblesville, Indiana, January 14, 2005. Center photograph is view looking north along State Road 19. Lower right photograph is view looking east at the U.S. Geological Survey streamgage, downstream of the Logan Street bridge. 


\section{Flood-Inundation Maps for the White River at Noblesville, Indiana}

By Zachary W. Martin

Prepared in cooperation with the Indiana Department of Transportation

Scientific Investigations Report 2017-5123 


\title{
U.S. Department of the Interior \\ RYAN K. ZINKE, Secretary
}

\section{U.S. Geological Survey William H. Werkheiser, Acting Director}

\author{
U.S. Geological Survey, Reston, Virginia: 2017
}

For more information on the USGS - the Federal source for science about the Earth, its natural and living resources, natural hazards, and the environment-visit https://www.usgs.gov or call 1-888-ASK-USGS.

For an overview of USGS information products, including maps, imagery, and publications, visit https://store.usgs.gov.

Any use of trade, firm, or product names is for descriptive purposes only and does not imply endorsement by the U.S. Government.

Although this information product, for the most part, is in the public domain, it also may contain copyrighted materials as noted in the text. Permission to reproduce copyrighted items must be secured from the copyright owner.

Suggested citation:

Martin, Z.W., 2017, Flood-inundation maps for the White River at Noblesville, Indiana: U.S. Geological Survey Scientific Investigations Report 2017-5123, 11 p., https://doi.org/10.3133/sir20175123.

ISSN 2328-0328 (online) 


\section{Acknowledgments}

The author wishes to thank Citizens Energy Group for cooperation in funding the operation and maintenance of the streamgage used for this study. Special thanks are given to the Indiana Department of Transportation for their cooperation in this study and to the National Weather Service for their continued support of the U.S. Geological Survey flood-inundation mapping program. 



\section{Contents}

Acknowledgments ……...................................................................................................................

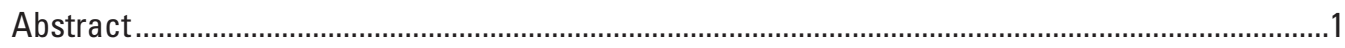

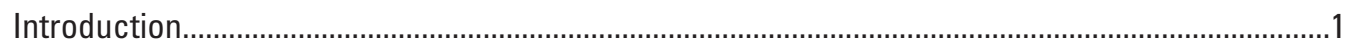

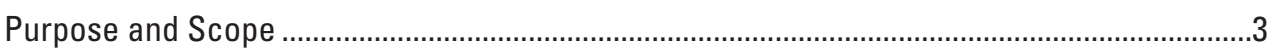

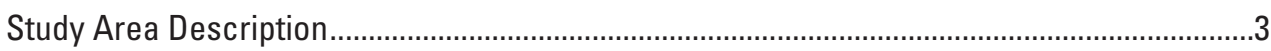

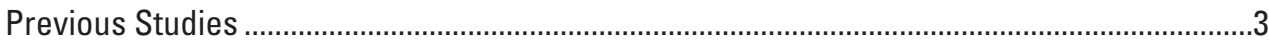

Creation of Flood-Inundation Map Library …….........................................................................

Computation of Water-Surface Profiles.................................................................................

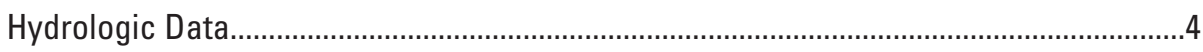

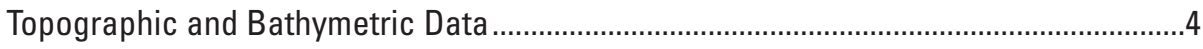

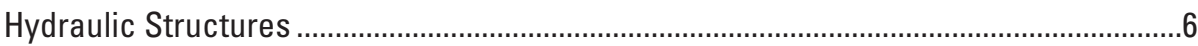

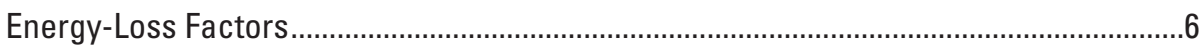

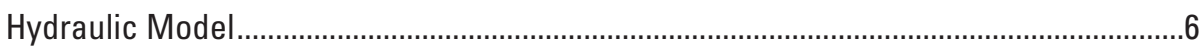

Development of Water-Surface Profiles ...........................................................................

Development of Flood-Inundation Maps ……………........................................................

Flood-Inundation Map Delivery ....................................................................................

Disclaimer for Flood-Inundation Maps .........................................................................10

Uncertainties and Limitations Regarding Use of Flood-Inundation Maps ......................10

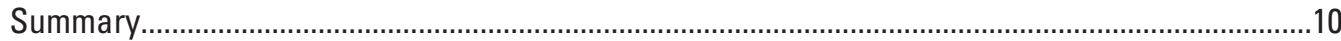

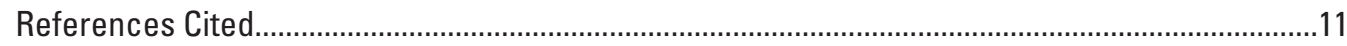

\section{Figures}

1. Map showing location of study reach for the White River at Noblesville, Indiana, and location of U.S. Geological Survey streamgage $03349000 \ldots \ldots \ldots \ldots \ldots \ldots \ldots \ldots \ldots \ldots \ldots \ldots \ldots \ldots . . .2$

2. Flood-inundation map for the White River at Noblesville, Indiana, corresponding to a stage of 24.0 feet at the U.S. Geological Survey streamgage 03349000.

\section{Tables}

1. U.S. Geological Survey streamgage information for the White River at Noblesville, Indiana

2. Estimated discharges for selected annual exceedance probabilities for the White River at Noblesville, Indiana

3. Estimated discharges for corresponding stages and water-surface elevations used in the hydraulic model of U.S. Geological Survey streamgage 03349000, White River at Noblesville, Indiana

4. Calibration of hydraulic model to target water-surface elevations at U.S. Geological Survey streamgage 03349000, White River at Noblesville, Indiana ..................................7

5. Calibration of hydraulic model to high-water mark elevations at selected locations along the White River for the floods of September 4, 2003, and May 6, 2017 


\section{Conversion Factors}

U.S. customary units to International System of Units

\begin{tabular}{|c|c|c|}
\hline Multiply & By & To obtain \\
\hline \multicolumn{3}{|c|}{ Length } \\
\hline foot $(\mathrm{ft})$ & 0.3048 & meter $(\mathrm{m})$ \\
\hline mile (mi) & 1.609 & kilometer $(\mathrm{km})$ \\
\hline \multicolumn{3}{|c|}{ Area } \\
\hline square mile $\left(\mathrm{mi}^{2}\right)$ & 2.590 & square kilometer $\left(\mathrm{km}^{2}\right)$ \\
\hline \multicolumn{3}{|c|}{ Flow rate } \\
\hline cubic foot per second $\left(\mathrm{ft}^{3} / \mathrm{s}\right)$ & 0.02832 & cubic meter per second $\left(\mathrm{m}^{3} / \mathrm{s}\right)$ \\
\hline \multicolumn{3}{|c|}{ Hydraulic gradient } \\
\hline foot per mile (ft/mi) & 0.1894 & meter per kilometer $(\mathrm{m} / \mathrm{km})$ \\
\hline
\end{tabular}

\section{Datum}

Vertical coordinate information is referenced to the North American Vertical Datum of 1988 (NAVD 88).

Horizontal coordinate information is referenced to the North American Datum of 1983 (NAD 83). Elevation, as used in this report, refers to distance above the vertical datum. 


\title{
Flood-Inundation Maps for the White River at Noblesville, Indiana
}

\author{
By Zachary W. Martin
}

\section{Abstract}

Digital flood-inundation maps for a 7.5-mile reach of the White River at Noblesville, Indiana, were created by the U.S. Geological Survey (USGS) in cooperation with the Indiana Department of Transportation. The flood-inundation maps, which can be accessed through the USGS Flood Inundation Mapping Science website at https://water.usgs.gov/osw/flood inundation/, depict estimates of the areal extent and depth of flooding corresponding to selected water levels (stages) at the White River at Noblesville, Ind., streamgage (USGS station number 03349000). Real-time stages at this streamgage may be obtained from the USGS National Water Information System at https://waterdata.usgs.gov/nwis or the National Weather Service (NWS) Advanced Hydrologic Prediction Service at http:/water.weather.gov/ahps/, which also forecasts flood hydrographs at the same site as the USGS streamgage (NWS site NBLI3).

Flood profiles were computed for the stream reach by means of a one-dimensional, step-backwater hydraulic modeling software developed by the U.S. Army Corps of Engineers. The hydraulic model was calibrated using the current (2016) stage-discharge rating at the USGS streamgage 03349000 , White River at Noblesville, Ind., and documented high-water marks from the floods of September 4, 2003, and May 6, 2017. The hydraulic model was then used to compute 15 watersurface profiles for flood stages at 1-foot (ft) intervals referenced to the streamgage datum ranging from $10.0 \mathrm{ft}$ (the NWS "action stage") to $24.0 \mathrm{ft}$, which is the highest stage interval of the current (2016) USGS stage-discharge rating curve and $2 \mathrm{ft}$ higher than the NWS "major flood stage." The simulated water-surface profiles were then combined with a geographic information system digital elevation model (derived from light detection and ranging data having a 0.98 -ft vertical accuracy and 4.9-ft horizontal resolution) to delineate the area flooded at each stage.

The availability of these maps, along with internet information regarding current stage from the USGS streamgage and forecasted high-flow stages from the NWS, will provide emergency management personnel and residents with information that is critical for flood response activities, such as evacuations and road closures, as well as for postflood recovery efforts.

\section{Introduction}

The city of Noblesville, Indiana, in central Hamilton County along the banks of the White River (fig. 1), has an estimated population of 51,969 (U.S. Census Bureau, 2010). Noblesville and surrounding communities have experienced flood stages numerous times, most recently in 2011, 2013, 2014, and 2015 (National Weather Service, 2017a). The highest documented flood at the U.S. Geological Survey (USGS) streamgage 03349000, White River at Noblesville, Ind., was a recorded peak stage value of 23.80 feet (ft) in March 1913 (U.S. Geological Survey, 2017d). The White River flows through central Hamilton County from the northeast to the south. The land around the White River corridor near Noblesville has been developed for residential, commercial, recreational, and agricultural use. At various stages and National Weather Service (NWS) Flood Categories, residential, commercial, recreational, and agricultural areas are affected by the floodwaters of the White River (National Weather Service, 2017a).

Before this study, emergency responders in Noblesville relied on a few information sources to make decisions on how to best alert the public and mitigate flood damages. An example of an information source is the Federal Emergency Management Agency flood insurance study (FIS) for Hamilton County, dated November 19, 2014 (Federal Emergency Management Agency, 2014). A second example of an information source is the USGS streamgage 03349000, White River at Noblesville, Ind., from which current (2017; U.S. Geological Survey, 2017d) and historic (since 1913; U.S. Geological Survey, 2017c) stages and discharges, including annual peak flows, can be obtained (https:/nwis.waterdata.usgs.gov/in/ nwis/uv/?site_no=03349000\&agency_cd=USGS). A third example of an information source is the NWS Advanced Hydrologic Prediction Service (AHPS), which displays the current USGS stage data and issues forecasts of stage for USGS streamgage 03349000, White River at Noblesville, Ind. (National Weather Service, 2017a). Although the NWS does not routinely issue forecasts for the White River at Noblesville, Ind., streamgage, forecasts are issued as needed during times of high flows (National Weather Service, 2017a). 


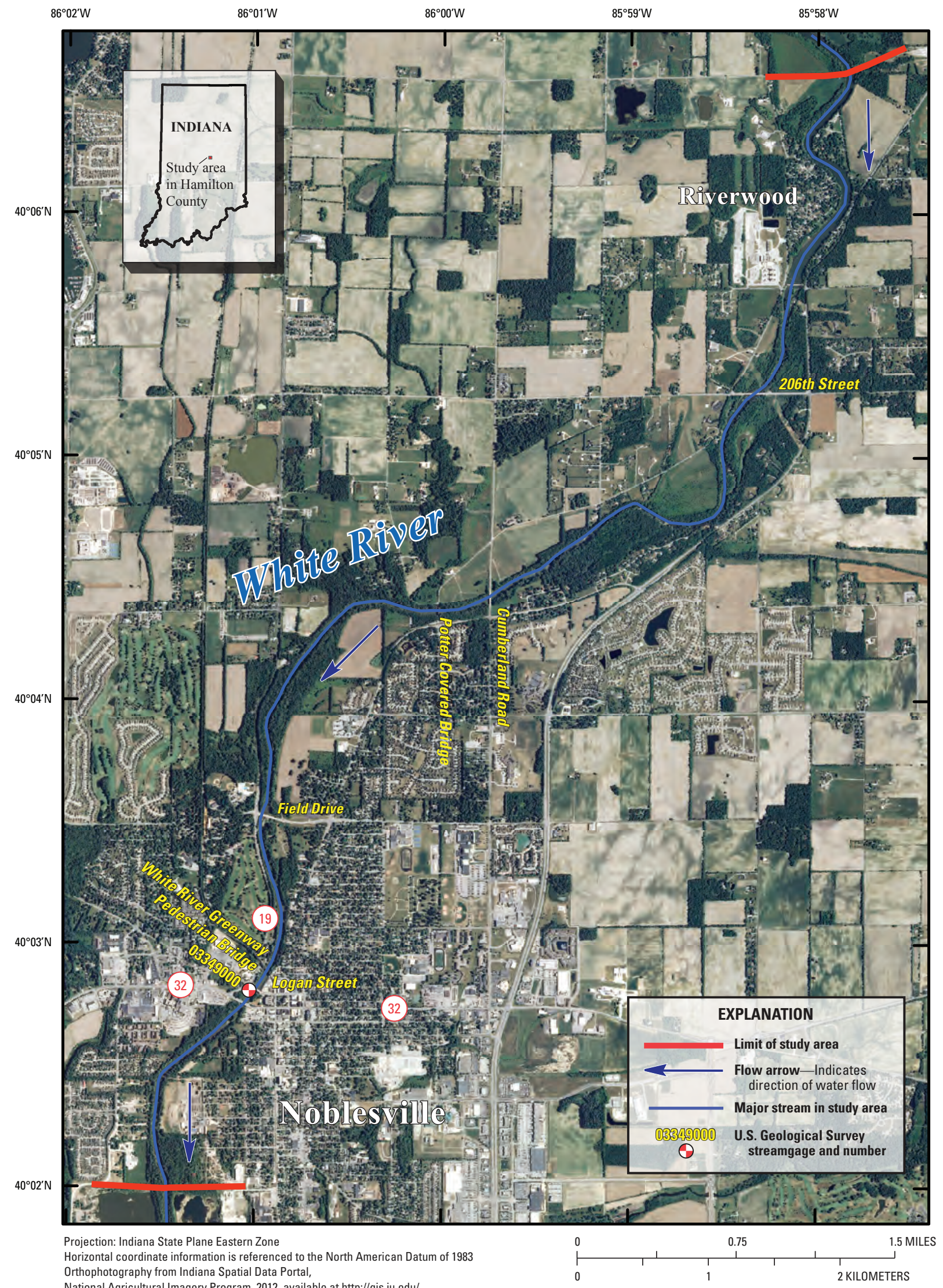

National Agricultural Imagery Program, 2012, available at http://gis.iu.edu/

Figure 1. Location of study reach for the White River at Noblesville, Indiana, and location of U.S. Geological Survey streamgage 03349000 . 
Although the current stage at a USGS streamgage is particularly useful for residents near a streamgage, the stage is of little use to residents farther upstream or downstream because the water-surface elevation is not constant along the stream reach. Knowledge of the water level at a streamgage is difficult to translate into depth and areal extent of flooding at points distant from the streamgage. A way to address these informational gaps is to produce a library of flood-inundation maps that are referenced to the stages recorded at the USGS streamgage. By referring to the appropriate map, emergency responders can discern the severity of flooding (depth of water and areal extent), identify roads that are or will soon be flooded, and make plans for notification or evacuation of residents in harm's way for some distance upstream and downstream from the streamgage. In addition, the capability to visualize the potential extent of flooding has motivated residents to take precautions and heed warnings that previously might have been disregarded. In 2017, the USGS, in cooperation with the Indiana Department of Transportation, led a project to produce a library of flood-inundation maps for the White River at Noblesville, Ind.

\section{Purpose and Scope}

This report describes the development of a series of estimated flood-inundation maps for the White River at Noblesville, Ind., and identifies where on the internet the maps can be viewed and ancillary data (geographic information system [GIS] flood polygons and depth grids) can be downloaded. The flood-inundation maps correspond to stages at USGS streamgage 03349000 and the NWS forecasted stages at the NWS site NBLI3, located at the same site as the USGS streamgage. The study covers a 7.5-mile (mi) reach along the White River, 1.8 mi upstream from the 206th Street bridge to $1.1 \mathrm{mi}$ downstream from the State Road 32 bridge (fig. 1).

The maps were produced for flood levels referenced to the stage recorded at USGS streamgage 03349000 , White River at Noblesville, Ind. (table 1); the streamgage structure is on the west bank of the White River and south of the Logan Street bridge (fig. 1). The maps cover a range in stage from 10.0 to $24.0 \mathrm{ft}$ above the streamgage datum. The $10.0-\mathrm{ft}$ stage is near bankfull and is defined by the National Weather
Service (2017b) as the "action stage" or the stage that, when reached by a rising stream, represents the level where the NWS or a partner needs to take some type of mitigation action in preparation for possible substantial hydrologic activity. The 24.0 -ft stage is the highest stage on the current USGS stagedischarge rating curve (USGS rating number 34.1, effective June 2, 2016). The 22.0-ft stage is the "major flood stage," as determined by the National Weather Service (2017b).

\section{Study Area Description}

The White River study reach is in the city of Noblesville, which is in central Indiana and has the third highest population of Hamilton County (U.S. Census Bureau, 2010). The stream is in the New Castle Till Plains and Drainageways physiographic section of the Central Till Plain Region (Gray, 2000). The drainage area is 832 square miles $\left(\mathrm{mi}^{2}\right)$ at the upstream end of the study reach and is $858 \mathrm{mi}^{2}$ at the downstream end of the study reach (U.S. Geological Survey, 2017a, 2017d). The study reach is about 7.5-mi long and has an approximate channel slope of 0.0006 (3.2 feet per mile). Land use along the study reach is residential, commercial, recreational, and agricultural development. The study reach is traversed by six local bridges; one railroad bridge; one State road bridge; one broad-crested, concrete, low-head dam; and one partially removed broad-crested, low-head dam.

\section{Previous Studies}

The current FIS for Hamilton County contains hydrologic and hydraulic analyses from previous and new studies effective November 19, 2014 (Federal Emergency Management Agency, 2014). The new FIS studies were completed by United Engineers and Architects and Christopher B. Burke Engineering, Ltd., on behalf of the Indiana Department of Natural Resources in 2004 (Federal Emergency Management Agency, 2014). The previous FIS analysis for Hamilton County was done by Christopher B. Burke Engineering, Ltd. on behalf of the Indiana Department of Natural Resources in 1999 (Federal Emergency Management Agency, 2014).

Table 1. U.S. Geological Survey streamgage information for the White River at Noblesville, Indiana.

[Station location is shown in figure 1. $\mathrm{mi}^{2}$, square mile; ft, foot; NAVD 88, North American Vertical Datum of 1988; $\mathrm{ft}^{3} / \mathrm{s}$, cubic foot per second; ${ }^{\circ}$, degree; ', minute; “, second]

\begin{tabular}{|c|c|c|c|c|c|c|c|c|}
\hline Station name & $\begin{array}{l}\text { Station } \\
\text { number }\end{array}$ & $\begin{array}{c}\text { Drainage } \\
\text { area } \\
\left(\mathrm{mi}^{2}\right)\end{array}$ & Latitude & Longitude & $\begin{array}{l}\text { Datum of gage } \\
\text { (ft, NAVD 88) }\end{array}$ & $\begin{array}{l}\text { Period of } \\
\text { record }\end{array}$ & $\begin{array}{c}\text { Maximum } \\
\text { documented } \\
\text { stage (ft) and } \\
\text { date }\end{array}$ & $\begin{array}{c}\text { Maximum } \\
\text { documented } \\
\text { discharge }\left(\mathrm{ft}^{3} / \mathrm{s}\right) \\
\text { and date }\end{array}$ \\
\hline
\end{tabular}


The FIS presents estimates of the peak discharges of 10 , 2 , and 1 percent annual exceedance probabilities (table 2) for the White River at Noblesville, Ind. (Federal Emergency Management Agency, 2014). Coordinated peak discharge frequency values are agreed upon by the Indiana Department of Natural Resources, the USGS, the Natural Resource Conservation Service, and the U.S. Army Corps of Engineers for select streams to maintain consistency in flood frequency values in the State of Indiana (Indiana Department of Natural Resources, 2017). In addition, the coordinated discharge values can be obtained on StreamStats (U.S. Geological Survey, 2017a).

\section{Creation of Flood-Inundation Map Library}

The USGS has standardized the procedures for creating flood-inundation maps for flood-prone communities (U.S. Geological Survey, 2017b) so that the process and products are consistent regardless of which USGS office is responsible for the work. Tasks specific to developing the flood maps for Noblesville, Ind., were as follows: (1) operation of the Noblesville streamgage and collection of streamflow data on the White River (table 1); (2) collection of topographic and bathymetric data for selected cross sections and geometric data for structures and bridges along the study reach; (3) estimation of energy-loss factors (roughness coefficients) in the stream channel and flood plain and determination of steady-flow data; (4) computation of water-surface profiles using the U.S. Army Corps of Engineers' Hydrologic Engineering Centers River Analysis System (HEC-RAS) computer program (Brunner, 2016a, 2016b, 2016c); (5) production of estimated floodinundation maps at various stream stages using the U.S. Army Corps of Engineers' Hydrologic Engineering Centers Geospatial River Analysis System (HEC-GeoRAS) computer program (Brunner, 2012) and GIS; and (6) preparation of the maps, as shapefile polygons that depict the areal extent of flood inundation and as depth grids that provide the depth of floodwaters, for display on a USGS flood-inundation mapping application.

\section{Computation of Water-Surface Profiles}

The water-surface profiles used to produce the 15 floodinundation maps in this study were computed with HEC-RAS, version 5.0.3 (Brunner, 2016a, 2016c). The HEC-RAS model is a one-dimensional step-backwater model that simulates water-surface profiles with steady-state (gradually varied) or unsteady-state flow computation options.

\section{Hydrologic Data}

The study reach includes USGS streamgage 03349000 , White River at Noblesville, Ind. (fig. 1; table 1), which has been in operation since October 1946. Water level (stage) is measured every 15 minutes, transmitted hourly by a satellite antenna at the streamgage, and made available on the internet through the USGS National Water Information System (U.S. Geological Survey, 2017c). Stage data from this streamgage are referenced to a local datum but can be converted to water-surface elevations referenced to the North American Vertical Datum of 1988 (NAVD 88) by adding $737.80 \mathrm{ft}$. Continuous records of streamflow are computed from a stage-discharge relation, which has been developed for the streamgage, and are available through the USGS National Water Information System website (U.S. Geological Survey, 2017c).

The flows used in the model simulations (table 3) were taken from the current stage-discharge relation for streamgage 03349000 (number 34.1, effective June 2, 2016) and corresponded to the target stages. Because no major tributaries join the White River in the 7.5-mi modeled reach, the flows from the stage-discharge relation were used for the complete reach for each water-surface profile (table 3 ).

\section{Topographic and Bathymetric Data}

All topographic data used in this study are referenced vertically to NAVD 88 and horizontally to the North American Datum of 1983. Cross section elevation data were obtained from a digital elevation model (DEM) that was derived from light detection and ranging (lidar) data that were collected as part of a statewide project during 2011-13 by Woolpert, Inc., Geospatial Services, Dayton, Ohio (Woolpert, Inc., 2011). The lidar data for Hamilton County were collected in 2011. The DEM was obtained from the Indiana Spatial Data Portal

Table 2. Estimated discharges for selected annual exceedance probabilities for the White River at Noblesville, Indiana.

$\left[\mathrm{mi}^{2}\right.$, square mile; $\mathrm{ft}^{3} / \mathrm{s}$, cubic foot per second; USGS, U.S. Geological Survey; data from Federal Emergency Management Agency, 2014]

\begin{tabular}{ccccc}
\hline \multirow{2}{*}{ Location on the White River } & $\begin{array}{c}\text { Drainage area } \\
\left(\mathbf{m i}^{2}\right)\end{array}$ & \multicolumn{3}{c}{$\begin{array}{c}\text { Estimated discharges }\left(\mathbf{f t}^{3} \mathbf{s}\right) \text { for indicated annual exceedance } \\
\text { probabilities, in percent }\end{array}$} \\
\cline { 3 - 5 } & & $\mathbf{1 0}$ & $\mathbf{2}$ & $\mathbf{1}$ \\
\hline USGS streamgage number 03349000 & 858 & 20,000 & 30,000 & 34,500 \\
\hline
\end{tabular}


(Indiana University, 2013). The original lidar data have a horizontal resolution of $4.9 \mathrm{ft}$ and vertical accuracy of $0.98 \mathrm{ft}$ at a 95-percent confidence level based on a root mean squared error of $0.49 \mathrm{ft}$ for the "open terrain" land-cover category. By these criteria, the lidar data support production of 2 -ft contours (Dewberry, 2012); the final DEM has a grid-cell size of $5 \mathrm{ft}$ by $5 \mathrm{ft}$ and a vertical accuracy of plus or minus $1 \mathrm{ft}$.

Because lidar data cannot provide ground elevations below the water surface of a stream, channel cross sections were surveyed by USGS field crews during March 2016. Cross sectional depths were measured using hydroacoustic instrumentation at 46 locations. A differential global positioning system with real-time kinematic technology was used to derive horizontal locations and the elevation of the water surface at each surveyed cross section. Georeferenced cross sections were made to coincide with the locations of the within-channel field-surveyed cross sections using the HEC-GeoRAS program, version 10.2 (Brunner, 2012). The HEC-GeoRAS program is a set of procedures, tools, and utilities for processing geospatial data in ArcGIS and was used to extract elevation data from the DEM for 46 cross sections. For these 46 cross sections, within-channel field data were directly merged with the DEM data.
The DEM-generated cross section data were used in conjunction with the RAS Mapper tool in HEC-RAS 5.0.3 to interpolate below-water ground elevations through the study reach (Brunner, 2016b). The RAS Mapper creates an interpolation surface in between each cross section. The interpolated surface is then used with the DEM-generated cross section data to create a grid of elevation data in between two cross sections. In this study, a grid of $5 \mathrm{ft}$ by $5 \mathrm{ft}$ was created for the in-channel DEM. The merged DEM, consisting of the lidar and in-channel data, was used to create the remaining 62 DEM-generated cross sections in HEC-GeoRAS for input to the HEC-RAS model. The 108 cross section lines were drawn to best represent flow vectors in the channel and flood plain and were spaced longitudinally every $400 \mathrm{ft}$ on average. Instructions for creating a terrain model of the channel data are presented in chapter 2 of the U.S. Army Corps of Engineers 2D Modeling User's Manual, Version 5.0 (Brunner, 2016b).

Table 3. Estimated discharges for corresponding stages and water-surface elevations used in the hydraulic model of U.S. Geological Survey streamgage 03349000, White River at Noblesville, Indiana.

[ft, foot; NAVD 88, North American Vertical Datum of 1988; $\mathrm{ft}^{3} / \mathrm{s}$, cubic foot per second]

\begin{tabular}{ccc}
\hline $\begin{array}{c}\text { Stage of water-surface } \\
\text { profile (ft) }\end{array}$ & $\begin{array}{c}\text { Water-surface elevation } \\
\text { (ft, NAVD 88) }\end{array}$ & $\begin{array}{c}\text { Estimated discharge at corresponding } \\
\text { water-surface profiles } \\
\text { (ft } \mathbf{3} \text { /s) }\end{array}$ \\
\hline 10.0 & 747.80 & 4,720 \\
11.0 & 748.80 & 5,610 \\
12.0 & 749.80 & 6,540 \\
13.0 & 750.80 & 7,510 \\
14.0 & 751.80 & 8,520 \\
15.0 & 752.80 & 9,550 \\
16.0 & 753.80 & 10,600 \\
17.0 & 754.80 & 12,200 \\
18.0 & 755.80 & 14,000 \\
19.0 & 756.80 & 16,000 \\
20.0 & 757.80 & 18,200 \\
21.0 & 758.80 & 20,500 \\
22.0 & 759.80 & 22,900 \\
23.0 & 760.80 & 25,500 \\
24.0 & 761.80 & 28,300 \\
\hline
\end{tabular}

${ }^{1}$ Water-surface profiles are 1-foot increments of stage referenced to the streamgage datum of the U.S. Geological Survey streamgage, White River at Noblesville, Ind. (station number 03349000). 


\section{Hydraulic Structures}

Ten structures, consisting of eight bridges (206th Street, Cumberland Road, Potter Covered Bridge, Field Drive, White River Greenway Pedestrian Bridge, Logan Street, State Road 32, and an abandoned railroad bridge [fig. 1]); one broad-crested, low-head dam; and one partially removed, broad-crested, low-head dam, have the potential to affect water-surface elevations during floods along the stream. Bridge-geometry and low-head dam-geometry data were obtained from field surveys led by personnel from the USGS in March 2016. Levees were not present in this modeled reach of the White River.

\section{Energy-Loss Factors}

Hydraulic analyses require the estimation of energy losses that result from frictional resistance exerted by a channel on flow. These energy losses are quantified by the Manning's roughness coefficient (" $n$ " value) (Phillips and Tadayon, 2006). Initial (precalibration) $n$ values were selected based on field observations, high-resolution aerial photographs, and the FIS hydraulic model (Federal Emergency Management Agency, 2014). Initially, an $n$ value of 0.035 was selected for sand and gravel bed material with minor channel vegetation. The overbank areas in the effective flow zones consisted of tree cover, permanent structures, and minimal open recreational or agricultural spaces, so an $n$ value of 0.090 was selected.

As part of the calibration process, the initial $n$ values were adjusted until the differences between simulated and observed water-surface elevations at the USGS streamgage and 30 high-water marks from the floods of September 4, 2003, and May 6, 2017, were minimized. Roughness-coefficient adjustment factors were varied by flow and adjusted until the simulated water-surface elevations approximated the target water-surface elevations. The actual $n$ values were computed by multiplying the initial $n$ value by each of the roughness-coefficient adjustment factors. The final $n$ values were $0.035-0.040$ for the main channel and $0.082-0.152$ for the overbank areas modeled in this analysis.

\section{Hydraulic Model}

The HEC-RAS analysis for this study was done using the steady-state flow computation option. Steady-state flow data consisted of flow regime, boundary conditions, and flows that produced water-surface elevations at the streamgage cross section that matched target water-surface elevations. These target elevations coincided with even 1-ft increments of stage, referenced to the local streamgage datum (U.S. Geological Survey, 2017d). Subcritical (tranquil) flow regime was assumed for the simulations. Normal depth, based on an estimated average water-surface slope of 0.00033 from survey data collected by USGS personnel, was used as the downstream boundary condition of the reach. The flows that were used in the model are included in the "Hydrologic Data" section.

The HEC-RAS hydraulic model was calibrated to the current stage-discharge relation (USGS rating no. 34.1, June 2, 2016) at USGS streamgage 03349000 , White River at Noblesville, Ind. The model was calibrated by adjusting Manning's $n$ values and channel cross section ineffective flow areas until the results of the hydraulic computations closely agreed with the observed water-surface elevations for given flows. Ineffective flow areas were determined based on heavy vegetation, hydraulic connectivity to the channel, and proximity to the channel. Differences between simulated and observed water-surface elevations for the 15 simulated flows at the USGS streamgage were equal to or less than $0.27 \mathrm{ft}$ (table 4). Differences between simulated water-surface elevations and surveyed high-water marks in the study reach for the floods of September 4, 2003, and May 6, 2017, were equal to or less than $0.66 \mathrm{ft}$ (table 5). The September 4, 2003, high-water mark data were collected for an event that reached a stage of $19.99 \mathrm{ft}$ at the USGS streamgage. The May 6, 2017, highwater mark data were collected at a stage near $18.3 \mathrm{ft}$ in comparison to the USGS streamgage. The high-water mark data obtained from the Indiana Department of Natural Resources have been noted as preliminary data not reviewed for accuracy (table 5). The Indiana Department of Natural Resources high-water mark data were originally surveyed in National Geodetic Vertical Datum of 1929; therefore, the high-water mark data were converted to NAVD 88 elevations (table 5) using a $-0.42 \mathrm{ft}$ correction from the VERTCON utility so the data could be compared to modeled water-surface elevations (National Geodetic Survey, 2017). The high-water mark data obtained by the U.S. Geological Survey were surveyed in NAVD 88 (table 5). The high-water marks are designated as river mile distance upstream from the mouth of the White River and river stationing upstream from the starting point of the hydraulic model in feet. The simulated water-surface elevations indicate that the model is capable of computing accurate water levels for a wide range of flows in the study reach. The datasets and model input used in this study are available through a data release at https://doi.org/10.5066/ F7MG7N0J (Martin, 2017).

\section{Development of Water-Surface Profiles}

The calibrated hydraulic model was used to generate water-surface profiles for 15 stages at 1.0 -ft intervals between 10 and $24 \mathrm{ft}$ as referenced to the local datum of USGS streamgage 03349000, White River at Noblesville, Ind. These stages correspond to elevations of 747.80 and $761.80 \mathrm{ft}$, NAVD 88, respectively. Discharges corresponding to the various stages were obtained from the current stage-discharge relation (USGS rating no. 34.1, June 2, 2016) (table 3) for USGS streamgage 03349000, White River at Noblesville, Ind. 
Table 4. Calibration of hydraulic model to target water-surface elevations at U.S. Geological Survey streamgage 03349000 , White River at Noblesville, Indiana.

[ft, foot; NAVD 88, North American Vertical Datum of 1988]

\begin{tabular}{cccc}
\hline $\begin{array}{c}\text { Stage of water-surface } \\
\text { profile } \\
\text { (ft) }\end{array}$ & $\begin{array}{c}\text { Target water-surface } \\
\text { elevation } \\
\text { (ft, NAVD 88) }\end{array}$ & $\begin{array}{c}\text { Modeled water-surface } \\
\text { elevation } \\
\text { (ft, NAVD 88) }\end{array}$ & $\begin{array}{c}\text { Difference in elevation } \\
\text { (ft) }\end{array}$ \\
\hline 10.0 & 747.80 & 748.07 & 0.27 \\
11.0 & 748.80 & 748.98 & 0.18 \\
12.0 & 749.80 & 749.86 & 0.06 \\
13.0 & 750.80 & 750.64 & -0.16 \\
14.0 & 751.80 & 751.69 & -0.11 \\
15.0 & 752.80 & 752.72 & -0.08 \\
16.0 & 753.80 & 753.73 & -0.07 \\
17.0 & 754.80 & 754.69 & -0.11 \\
18.0 & 755.80 & 755.69 & -0.11 \\
19.0 & 756.80 & 756.75 & -0.05 \\
20.0 & 757.80 & 757.75 & -0.05 \\
21.0 & 758.80 & 758.77 & -0.03 \\
22.0 & 759.80 & 759.76 & -0.04 \\
23.0 & 760.80 & 760.78 & -0.02 \\
24.0 & 761.80 & 761.81 & 0.01 \\
\hline
\end{tabular}

\section{Development of Flood-Inundation Maps}

Flood-inundation maps were created for a reach of the White River at Noblesville, Ind. The maps were created in a GIS by combining the 15 water-surface profiles and DEM data. The DEM data were derived from the same lidar data described in the "Topographic and Bathymetric Data" section and, therefore, have an estimated vertical accuracy of plus or minus $1 \mathrm{ft}$. In addition, the in-channel elevation data were merged with the lidar DEM data to provide a reasonable estimate of the stream bathymetry. Estimated flood-inundation boundaries for each simulated profile were developed with HEC-GeoRAS software (Brunner, 2012), which allows the preparation of geometric data for import into HEC-RAS and processes simulation results exported from HEC-RAS (Brunner, 2016a, 2016c). Shapefile polygons and depth grids of the inundated areas for each profile were modified, as required, in the ArcMap application of ArcGIS (Esri, 2017) to ensure a hydraulically reasonable transition of the flood boundaries between modeled cross sections.

Any inundated areas that were detached from the main channel were examined to identify subsurface hydraulic connections with the main river, such as through culverts under roadways. Where such connections existed, the mapped inundated areas were retained in their respective flood maps; otherwise, the erroneously delineated parts of the flood extent were deleted. The flood-inundation areas are overlaid on highresolution, georeferenced, aerial photographs of the study area. Bridge surfaces for the White River are displayed as inundated regardless of the actual water-surface elevation in relation to the lowest structural chord of the bridge or the bridge deck. Estimates of water depth can be obtained from the depth-grid data that are included with the presentation of the flood maps on an interactive USGS mapping application described in the "Flood-Inundation Map Delivery" section. The flood map corresponding to the highest simulated water-surface profile, a stage of $24.0 \mathrm{ft}$, is shown in figure 2 .

\section{Flood-Inundation Map Delivery}

A Flood Inundation Mapping Science website has been established to make USGS flood-inundation study information available to the public (U.S. Geological Survey, 2017b). The website (https://fim.wim.usgs.gov/fim/) links to a mapping application that presents map libraries and provides detailed information on flood extents and depths for modeled sites. The mapping application enables the production of customized flood-inundation maps from the map library for the White River at Noblesville, Ind. A link on this website connects to the USGS National Water Information System (U.S. Geological Survey, 2017d), which presents the current stage and streamflow at USGS streamgage 03349000 , White River at Noblesville, Ind., to which the inundation maps are referenced. A second link connects to the NWS AHPS website (National Weather Service, 2017a) so that the user can obtain applicable information on forecasted peak stage. The estimated flood-inundation maps are displayed in sufficient detail 
Table 5. Calibration of hydraulic model to high-water mark elevations at selected locations along the White River for the floods of September 4, 2003, and May 6, 2017.

[HWM, high-water mark; mi, mile; ft, foot; NAVD 88, North American Vertical Datum of 1988]

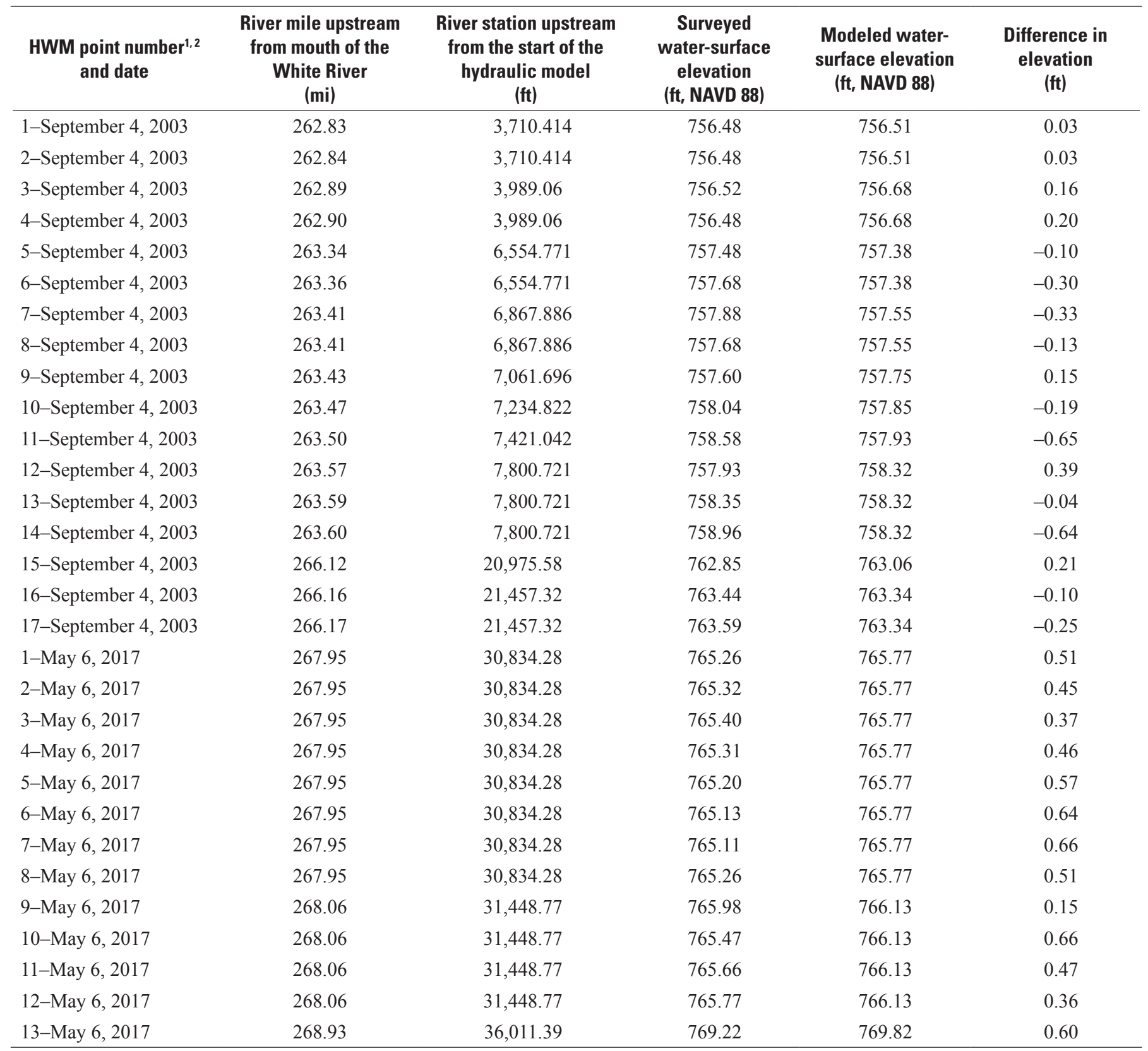

'Indiana Department of Natural Resources high-water marks surveyed (noted as preliminary data, not reviewed for accuracy) for the flood of September 4, 2003.

${ }^{2}$ U.S. Geological Survey high-water marks surveyed for the flood of May 6, 2017. 


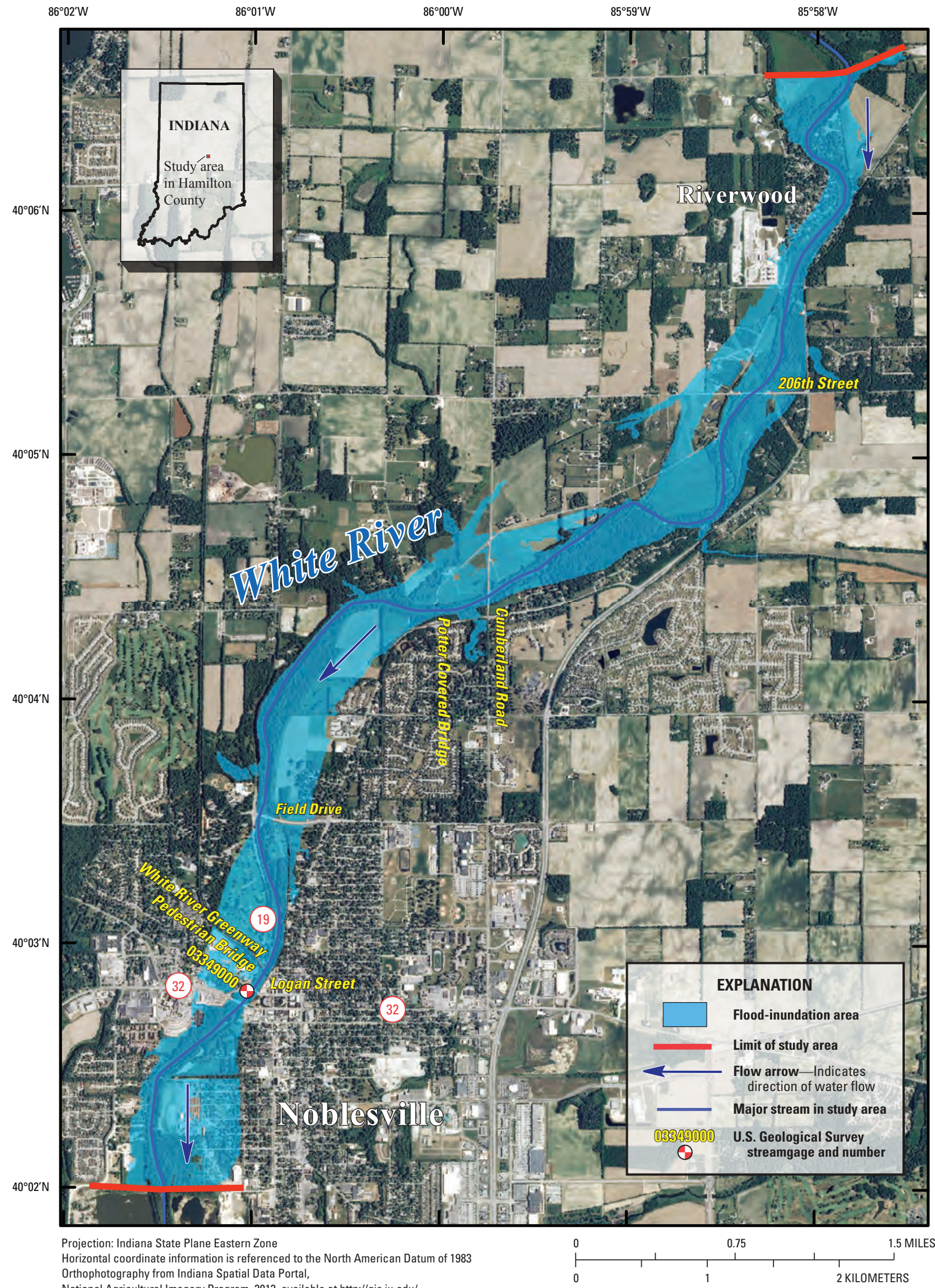

National Agricultural Imagery Program, 2012, available at http://gis.iu.edu/

Figure 2. Flood-inundation map for the White River at Noblesville, Indiana, corresponding to a stage of 24.0 feet at the U.S. Geological Survey streamgage 03349000. 
so that preparations for flooding and decisions for emergency response can be made efficiently. Depending on the flood magnitude, roadways are shown as shaded (inundated and likely impassable) or not shaded (dry and passable) to facilitate emergency planning and use. Bridges are shaded - that is, shown as inundated - regardless of the flood magnitude. A shaded building should not be interpreted to mean that the structure is completely submerged but that bare earth surfaces near the building are inundated. The water depth (as indicated in the mapping application by clicking the cursor over an inundated area) near the building would be an estimate of the water level inside the structure, unless flood-proofing measures had been implemented.

\section{Disclaimer for Flood-Inundation Maps}

The flood-inundation maps should not be used for navigation or regulatory, permitting, or other legal purposes. The USGS provides these maps "as is" for a quick reference, emergency planning tool but assumes no legal liability or responsibility resulting from the use of this information.

\section{Uncertainties and Limitations Regarding Use of Flood-Inundation Maps}

Although the flood-inundation maps represent the boundaries of inundated areas with a distinct line, some uncertainty is associated with these maps. The flood boundaries shown were estimated based on water stages and streamflows at selected USGS streamgages. Water-surface elevations along the stream reaches were estimated by steady-state hydraulic modeling, by assuming unobstructed flow, and by using streamflows and hydrologic conditions anticipated at the USGS streamgage. The hydraulic model reflects the landcover characteristics and any bridge, dam, levee, or other hydraulic structures existing as of March 2016. Unique meteorological factors (timing and distribution of precipitation) may cause actual streamflows along the modeled reach to vary from those assumed during a flood, which may lead to deviations in the water-surface elevations and inundation boundaries shown. Additional areas may be flooded because of unanticipated conditions such as changes in the streambed elevation or roughness, backwater into major tributaries along a main stem river, backwater from localized debris or ice jams, or backwater into storm sewers and detention basins. The accuracy of the floodwater extent portrayed on these maps will vary with the accuracy of the DEM used to simulate the land surface.

If this series of flood-inundation maps will be used in conjunction with NWS river forecasts, the user should be aware of additional uncertainties that may be inherent or factored into NWS forecast procedures. The NWS uses forecast models to estimate the quantity and timing of water flowing through selected stream reaches in the United States. These forecast models (1) estimate the amount of runoff generated by precipitation and snowmelt, (2) simulate the movement of floodwater as it flows downstream, and (3) predict the flow and stage (and water-surface elevation) for the stream at a given location (AHPS forecast point) throughout the forecast period (every 6 hours and 3 to 5 days out in many locations). For more information on AHPS forecasts, see http://water.weather.gov/ahps/pcpn_and_river_forecasting.pdf.

Additional sources of uncertainty are the modeled watersurface elevations upstream from the low-head dam, near Riverwood, Ind. Only a single high-water mark was collected and used to calibrate this part of the study reach; however, modeled water-surface elevations correspond to the NWS AHPS Flood Impact Statements as closely as possible for various stages (National Weather Service, 2017a). Additional uncertainties and limitations pertinent to this study may be described elsewhere in this report.

\section{Summary}

A series of 15 digital flood-inundation maps were developed in cooperation with the Indiana Department of Transportation for U.S. Geological Survey (USGS) streamgage 03349000 , White River at Noblesville, Indiana. The maps cover a reach about 7.5 miles long, 1.8 miles upstream from the 206th Street bridge to 1.1 miles downstream from the State Road 32 bridge. The maps were developed using the U.S. Army Corps of Engineers' Hydrologic Engineering Centers River Analysis System and Hydrologic Engineering Centers Geospatial River Analysis System to compute water-surface profiles and to delineate estimated flood-inundation areas and depths of flooding for selected stream stages. The HEC-RAS hydraulic model was calibrated to the current (2016) stage-discharge relation at USGS streamgage 03349000 , White River at Noblesville, Ind., and to the floods of September 4, 2003, and May 6, 2017. The model was used to compute 15 water-surface profiles for flood stages at 1-foot ( $\mathrm{ft}$ ) intervals referenced to the streamgage datum and ranging from $10.0 \mathrm{ft}$ or the National Weather Service "action stage" to $24.0 \mathrm{ft}$, which is the highest stage interval of the current (2016) USGS stage-discharge rating curve and $3 \mathrm{ft}$ higher than the National Weather Service "major flood stage." The simulated water-surface profiles were then combined with a geographic information system digital elevation model derived from light detection and ranging data to delineate estimated flood-inundation areas as shapefile polygons and depth grids for each profile. These flood-inundation polygons were overlaid on high-resolution, georeferenced aerial photographs of the study area. The flood maps are available through a mapping application that can be accessed on the USGS Flood Inundation Mapping Science website (https://water.usgs.gov/ osw/flood_inundation).

The interactive maps on this mapping application can give users a general indication of depth of water at any point by clicking within the shaded areas using the mouse cursor. 
These maps, in conjunction with the real-time stage data from USGS streamgage 03349000 , White River at Noblesville, Ind., and forecasted flood stage data from the National Weather Service Advanced Hydrologic Prediction Service, will help to guide the general public in taking individual safety precautions and will provide emergency management personnel with a tool to efficiently manage emergency flood operations and postflood recovery efforts.

\section{References Cited}

Brunner, G.W., 2012, HEC-GeoRAS, GIS tools for support of HEC-RAS using ArcGIS 10-User's manual, version 10: U.S. Army Corps of Engineers, Hydrologic Engineering Center [variously paged].

Brunner, G.W., 2016a, HEC-RAS, River Analysis System hydraulic reference manual, version 5: U.S. Army Corps of Engineers, Hydrologic Engineering Center, [variously paged].

Brunner, G.W., 2016b, HEC-RAS, River Analysis System, 2D modeling user's manual, version 5: U.S. Army Corps of Engineers, Hydrologic Engineering Center, [variously paged].

Brunner, G.W., 2016c, HEC-RAS River Analysis System user's manual, version 5: U.S. Army Corps of Engineers, Hydrologic Engineering Center, [variously paged].

Dewberry, 2012, National enhanced elevation assessment: Fairfax, Va., Dewberry, 84 p., accessed January 25, 2017, at http://www.dewberry.com/docs/default-source/documents/ neea_final-report_revised-3-29-12.pdf?sfvrsn $=0$.

Esri, 2017,About ArcGIS: Esri web page, accessed January 25, 2017, at http://www.esri.com/software/arcgis/.

Federal Emergency Management Agency, 2014, Flood insurance study, Hamilton County, Indiana and incorporated areas: Washington D.C., 86 p.

Gray, H.H., 2000, Physiographic divisions of Indiana: Indiana Geological Survey Special Report 61, 15 p., 1 pl.

Indiana Department of Natural Resources, 2017, Coordinated discharges of selected streams in Indiana: Indiana Department of Natural Resources web page, accessed January 25, 2017, at http://www.in.gov/dnr/water/4898.htm.

Indiana University, 2013, Indiana spatial data portal: Indiana University web page, accessed January 25, 2017, at http://gis.iu.edu/.
Martin, Z.W., 2017, White River at Noblesville, Indiana, flood-inundation model and GIS data: U.S. Geological Survey data release, accessed October 2017, at https://doi.org/10.5066/F7MG7N0J.

National Geodetic Survey, 2017, VERTCON—North American Vertical Datum Conversion: National Geodetic Survey web page, accessed January 25, 2017, at http://www.ngs.noaa.gov/TOOLS/Vertcon/vertcon.html.

National Weather Service, 2017a, Advanced Hydrologic Prediction Service, White River at Logan Street in Noblesville: National Weather Service web page, accessed April 25, 2017, at http://water.weather.gov/ahps2/ hydrograph.php?wfo=ind\&gage=NBLI3 .

National Weather Service, 2017b, National Weather Service glossary: National Weather Service web page, accessed April 25, 2017, at http://w1.weather.gov/glossary/.

Phillips, J.V., and Tadayon, Saeid, 2006, Selection of Manning's roughness coefficient for natural and constructed vegetated and non-vegetated channels, and vegetation maintenance plan guidelines for vegetated channels in central Arizona: U.S. Geological Survey Scientific Investigations Report 2006-5108, 41 p.

U.S. Census Bureau, 2010, 2010 census interactive population search IN-Indiana: U.S. Census Bureau web page, accessed April 25, 2017, at http://www.census.gov/2010census/ popmap/ipmtext.php?fl=18.

U.S. Geological Survey, 2017a, The StreamStats ProgramIndiana: U.S. Geological Survey web page, accessed April 25, 2017, at https://water.usgs.gov/osw/streamstats/ indiana.html.

U.S. Geological Survey, 2017b, USGS flood inundation mapping science: U.S. Geological Survey web page, accessed April 25, 2017, at https://water.usgs.gov/osw/ flood_inundation.

U.S. Geological Survey, 2017c, USGS surface-water data for the Nation: U.S. Geological Survey National Water Information System-Web interface, accessed April 25, 2017, at https://doi.org/10.5066/F7P55KJN.

U.S. Geological Survey, 2017d, USGS 03349000, White River at Noblesville, Indiana: U.S. Geological Survey National Water Information System - Web interface, accessed April 25, 2017, at https://waterdata.usgs.gov/in/nwis/ uv?site_no $=03349000$.

Woolpert, Inc., 2011, Woolpert Order No. 71177, Indiana Statewide Imagery and Lidar Program, remote sensing image: Dayton, Ohio, Woolpert, Inc., metadata available at http://gis.iu.edu/files/documents/in2011_ortho.txt. 
For more information about this publication, contact:

Director, Ohio-Kentucky-Indiana Water Science Center

U.S. Geological Survey

5957 Lakeside Boulevard,

Indianapolis, IN 46278-1996

For additional information, visit https://in.water.usgs.gov/

Publishing support provided by the

Madison and Rolla Publishing Service Centers 

